\title{
Program Evaluation Basic Education of Special Service Class at Surabaya Primary School
}

\author{
Ganes Gunansyah ${ }^{\mathrm{a}}$, Ulhaq Zuhdi ${ }^{\mathrm{b}}$, Mochammad Miftachul Huda \\ Departemen Elementary Teacher Education, Universitas Negeri Surabaya \\ Surabaya, Indonesia
}

Corresponding e-mail: aganesgunansyah@unesa.ac.id, 'bmiftahuda090514@gmail.com

\begin{abstract}
The purpose of this study is to describe the implementation of basic education programs Special Class Service (KLK) in Primary School Surabaya. Aspects which are observed include: compatibility and appropriateness of program design, readiness of resource support, teacher and student involvement, implementation of learning, level of goals achievement, and implications for program participants. Through qualitative research with CIPP evaluation model analysis (Context Input Process Product), the researcher collected data through observation, documentation study and interview with Primary School stakeholders who are KLK organizer in Surabaya, Indonesia. The results of this study showed the implementation of KLK program runs quite well with the achievement of program objectives to capture the compulsory school age children who have not yet or drop out to obtain opportunities for education services in schools. Supporting factors the program are the availability of infrastructure facilities, the fulfillment of qualifications of teachers, government funding assistance in the form of school supplies. Inhibiting factors of the program are limited space, lack of attention and support of parents, socialization of programs that have not maximized, recruitment system that is not in accordance with the planning. This program has contributed to government efforts in facilitating education services for all.
\end{abstract}

Keywords: $\quad$ program evaluation, special service class

\section{INTRODUCTION}

Street children face the problem of social exclusion due to illness and poverty which pushes them into a life full of risk and danger ${ }^{1}$. Problematic Children will encounter more physical stresses such as chaotic environments and psychosocial stressors such as family chaos so that chronic stress accumulation will disrupt the self-regulation process that helps children cope with external demands ${ }^{5}$.

Responding to this matter, currently Surabaya City Government has organized Retrieval Remedial (RR) program or commonly known as special service class (KLK), which is program aimed at recruiting or recalling compulsory school age children who have not or no school to get education in school. Students leave public schools to attend special service schools because of the limited school to meet their academic, social, emotional, behavioral, and access needs ${ }^{7}$. Several obstacles in the implementation of inclusive education such as the need for collaboration in planning time of implementation, availability of diverse resources, and the existence of a professional learning community ${ }^{8}$. The problem of student motivation is the presence of students who become the backbone of the family in earning a living, or live alone and become groups of street children ${ }^{10}$.

The purpose of this study is to describe the implementation of basic education, especially the Elementary School KLK program in overcoming the problem of high dropout rate in Surabaya. Aspects observed include how to illustrate the suitability and feasibility of KLK program design, resource support readiness, teacher and student involvement, learning implementation, achievement level objectives, and implications for program participants. Limitations of the room, lack of attention and support of parents, socialization programs that have not maximized, recruitment system that is not in accordance with the planning is a number of obstacles that are still encountered in KLK programming. It is expected that this program can contribute to government efforts in facilitating education services for all.

\section{METHODS}

The research approach used is qualitative approach with descriptive method. As informants are principals and educators Tandes Lor Surabaya Primary School, community leaders, parents, as well as officers at the technical implementing unit Surabaya education office. In the research design using instrument and CIPP (context evaluation, input evaluation, process evaluation, and product evaluation). Through qualitative approach and CIPP evaluation analysis model, the data obtained based on KLK program components include: (1) program understanding; (2) program planning; (3) readiness of program organizers; (4) requirements of educators and learners; (5) curriculum; (6) infrastructure facilities; (7) stakeholder support; (8) program socialization; (9) student recruitment system and KLK teacher; (10) teaching and learning activities; 
And (11) the results of program implementation. In addition, the data is also obtained based on the supporting components of the KLK program (primary and secondary data sources). The data analysis technique uses inductive descriptive with data reduction, data presentation, and conclusion through triangulation test.

\section{RESULT AND DISCUSSION}

KLK program is a program created by the government with the aim to capture children of compulsory education age of 8-14 years who have not or no school to be included in the education system or school. Furthermore, the understanding of the program and its objectives must be understood by the program implementers before implementing the program. Based on the informants, principals, teachers, and education offices KLK program known by program organizers is good. The understanding is shown by the explanation that the purpose of KLK is to capture and give special attention (in class) to school-age children who are late or not attending school because of family problems and are aimed at capturing and handling street children, Not yet or not school or in other words children who have problems in his family. The services and support provided to individuals with disabilities improve the extent to which they actually benefit from education and participation in all the community 9 .

The implementation of KLK program at Tandes Lor Primary School Surabaya is in accordance with Law no. 20 of 2003 on the National Education System that every citizen has the same right to obtain quality education and nine years of compulsory education. Thus the overall understandings of informants already understand well the purpose, goals and objectives of KLK program.

Planning KLK program implementation known, has been started by giving socialization program to the stakeholders. Next, recruitment of KLK students and teachers, preparing facilities including determining the schedule of implementation of teaching and learning process. Based on the teacher before implementing the KLK program first socialize the program to the parents and the community, then find the directed students, then the principal to provide additional teaching burden on the teacher appointed.

Next about the period of KLK program is carried out for six months to one year. However, if the student has been in KLK for a given period of time, but is considered unable to join regular classes, students will remain in KLK until they are considered capable of joining regular classes. Initial plan implementation every Monday to Saturday same as regular class, only difference is in time that if class regular entry starting at $07.00 \mathrm{~s} / \mathrm{d}$ at 12.00 meanwhile for KLK entrance starting at $06.30 \mathrm{~s} / \mathrm{d}$ 10.00 WIB. This is according to the KLK teacher because it adjusts from the students' interest and as an adaptation for those who will be included in the regular class if he is considered having capability. However, the informant's explanation of the program planning has not been supported by physical evidence in the form of document of work program plan such as the implementation schedule of Learning and Teaching Activity.

The mechanism of KLK program implementation cannot be separated from the readiness of the program organizers or the school program organizers. The readiness is important in the implementation of a program where the school or educational institution is the place where the object of the KLK program (children of compulsory age) is handled. In addition, the readiness of program providers is very important in order to achieve the goal, if the program organizers are not ready in running the program then the program will not run optimally or in other words not in accordance with the objectives to be achieved.

Based on the informants from Primary School organizer has the readiness to run the program and has been in accordance with the requirements and has been through various considerations of the ability to run the KLK program optimally. These requirements include (1) the students as the object of the program, (2) the readiness of the school shown by the educators, the infrastructure, and the availability of time and the close access between the distance of the student's house and the Primary Education program manager. Teachers play an important role in enhancing all the competencies of learners and preparing for global life 21 st century, the use of contextual and responsive pedagogy, and productive cultural and family / community engagement ${ }^{6}$.

If there is one condition that is not met, then the KLK program implementation can still run. If the unmeet requirement is space, then the alternative can be implemented after the regular class period course finishes. Meanwhile, if the conditions are not met is teacher, then it can recruit teacher from outside the school. On the contrary, if the unmet condition is the student, the program automatically does not work, considering the target / object of the KLK program is the compulsory school age children who have not or no school.

In general, teachers and KLK students already meet the criteria / requirement that have been determined. This is supported by the result of the documentation study shown by SKPBM (Decision on the Distribution of Teaching Burden) stipulated by the Principal where it is stated that the distribution of teaching burden to the teacher for the KLK program class is a graduate degree. However, there are still teachers who do not teach according to SKPBM.

The curriculum of KLK program used is the same curriculum applied to regular classes with learning materials that adjust students' ability. However, the findings indicate that the 
implementation has not been supported by the existence of the existing curriculum document or lesson plan. Nevertheless, according to the observation, it is known that teachers have been seen to develop learning materials that are adapted to the characteristics and abilities of KLK students. The weaknesses associated with KLK's curriculum are related to teaching experience, limited teacher training, and have not fully mastered knowledge and instructional skills ${ }^{4}$.

Infrastructure facilities in KLK programming have been fulfilled where KLK programs are conducted in separate classrooms that are not combined with the regular class. However, there are other findings in which the infrastructure components are considered less effective because of the existence of these three students in one room with administrative space. Obstacles in the management of specific service classes such as teacher experience, student disability, role conflict, and administrative support are important factors in teacher fatigue in special education services ${ }^{2}$.

Concerning with stakeholder support and involvement, KLK has encouraged the active involvement and full participation of various parties including the government, principals, KLK teachers, parents and the community. While the socialization program KLK organized by Tandes Lor Primary Teacher Surabaya has not been implemented optimally because the socialization has not been done in a system well so that the impact on the general public is not yet aware of the KLK program at Tandes Lor Primary Teacher Surabaya.

In the learning process KLK program implemented slightly different from the planning that has been planned in the beginning. The process is carried out every Monday to Friday which starts from $06.30-10.00$ WIB. In general, it is almost the same as the regular classroom learning process where the learning activities are carried out in the classroom and receive the learning material from the teacher as in general. In addition, the delivery of materials in learning is also the same as the regular class that is supported with the book material and also supported by the learning media in accordance with the material being studied.

The learning approach used is individual, both for KLK students and regular students. A variety of diverse student characteristics and backgrounds are the reasons for using the approach. The Principal revealed that in the learning done in KLK an individual approach because each individual or each child is believed to have different characteristics.

\section{CONCLUSION}

The implementation of KLK program in Tandes Lor Primary School Surabaya has been running well with the achievement of the objectives of KLK program that make children have compulsory education age who have not or no school to be able to school, readiness to facilitate the mental, academic, and social development of KLK students and to prepare infrastructure components, Socialization, curriculum, recruitment and implementation system are adjusted based on the planning that has been declared.

Supporting factors of the KLK program include the availability of rooms, available time of performing the activity, the presence of teachers teaching and assistance from the government for KLK students in the form of school supplies. Meanwhile, the limitation factor of KLK is lack studying space, the socialization of the program that has not been implemented maximally, the recruitment system is not in accordance with the planning, the lack of student learning, the lack of attention of parents to the education of their children and the incompatibility of KLK teachers.

The stakeholder responses from the government, principals, teachers, parents or communities involved demonstrate good support in helping to deal with compulsory children who are late coming to schol.

\section{REFERENCES}

[1] Abdullah MA, Basharat Z, Lodhi O, Wazir MH, Khan HT, Sattar NY, Zahid A. (2014), A qualitative exploration of Pakistan's street children, as a consequence of the poverty-disease cycle. Infectious diseases of poverty. Mar 24;3(1):11.

[2] Brunsting NC, Sreckovic MA, Lane KL. (2014), Special education teacher burnout: A synthesis of research from 1979 to 2013. Education and treatment of children. 37(4):681-711.

[3] Cardoso AR, Verner D. School drop-out and push-out factors in Brazil: The role of early parenthood, child labor, and poverty.

[4] Cook BG. (2002), Inclusive attitudes, strengths, and weaknesses of pre-service general educators enrolled in a curriculum infusion teacher preparation program. Teacher Education and Special Education. Jul;25(3):262-77.

[5] Evans GW, Kim P. (2013), Childhood poverty, chronic stress, self-regulation, and coping. Child Development Perspectives, Mar 1;7(1):43-8.

[6] Ford BA, Stuart DH, Vakil S. (2014), Culturally Responsive Teaching in the 21 st Century Inclusive Classroom. Journal of the International Association of Special Education. Sep 1;15(2).

[7] Kelly A, Devitt C, O'Keeffe D, Donovan AM. (2014), Challenges in Implementing Inclusive Education in Ireland: Principal's Views of the Reasons Students Aged 12+ Are Seeking Enrollment to Special Schools. Journal of Policy and Practice in Intellectual Disabilities. Mar $1 ; 11(1): 68-81$.

[8] Katz J. (2015), Implementing the Three Block Model of Universal Design for Learning: effects 
on teachers' self-efficacy, stress, and job satisfaction in inclusive classrooms K-12. International Journal of Inclusive Education. Jan 2;19, 1, pp. 1-20.

[9] Morgan PL, Frisco ML, Farkas2 G, Hibel J. (2017), Republication of "A Propensity Score Matching Analysis of the Effects of Special
Education Services". The Journal of Special Education. Feb; 50, 4, pp. 197-214.

[10] Wahid A, Shodiq M. Manajemen Penyelenggaraan Pendidikan Model Kelas Layanan Khusus (Studi Multisitus di SDN Kotalimo 10 Mekar dan SDN Tanjungan 5 Mekar).(Disertasi). DISERTASI dan TESIS Program Pascasarjana UM. 2009 Aug 24. 